\title{
New and little known sepsid flies (Diptera: Sepsidae) from Vietnam
}

\section{Новые и малоизвестные виды муравьевидок (Diptera: Sepsidae) из Вьетнама}

\author{
A.L. Ozerov ${ }^{1}$, M.G. Krivosheina ${ }^{2}$

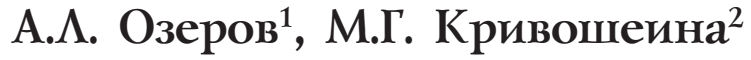

\author{
${ }^{1}$ Zoological Museum, Moscow Lomonosov State University, Bol'shaya Nikitskaya 6, Moscow 125009, Russia. \\ E-mail: ozerov2455@rambler.ru \\ 1 Зоологический музей, Московский государственный университет им. М.В. Ломоносова, Большая Никитская ул., 6, Москва \\ 125009, Россия. \\ ${ }^{2}$ A.N. Severtsov Institute of Ecology and Evolution, Russian Academy of Sciences, 119071 Moscow, Russia. \\ E-mail: dipteramarina@rambler.ru \\ ${ }^{2}$ Институт проблем экологии и эволюции им. А.Н.Северцова РАН, Ленинский проспект, 33 , Москва 119071, Россия.
}

KEY WORDS: Diptera, Sepsidae, Dicranosepsis, new species, Nemopoda, Oriental Region, Vietnam.

КЛЮЧЕВЫЕ СЛОВА: Diptera, Sepsidae, Dicranosepsis, новый вид, Nemopoda, Ориентальная область, Вьетнам.

ABSTRACT. A new species of Sepsidae - Dicranosepsis barbatula sp.n. from Vietnam is described. The genus Nemopoda Robineau-Desvoidy, 1830 with the species $N$. pectinulata Loew, 1873 is registered in Vietnam for the first time.

РЕЗЮМЕ. Дано описание нового вида из семейства Sepsidae - Dicranosepsis barbatula sp.n. по материалам из Вьетнама. Род Nemopoda Robineau-Desvoidy, 1830 с видом $N$. pectinulata Loew, 1873 впервые отмечен для Вьетнама.

\section{Introduction}

The fauna of Vietnam Sepsidae is studied better, than those of many countries of Oriental Region. Iwasa and Thinh [2012] recorded 52 species from 9 genera of Sepsidae in this country. Additional four new sepsid species were described from the north of Vietnam [Ozerov \& Krivosheina, 2011; Ozerov, 2012; Ozerov \& Krivosheina, 2012]. Besides the genus Pseudonemopoda Duda, 1926 was registered for the first time in Vietnam by the same authors [Ozerov \& Krivosheina, 2012].

38 species from 8 genera were previously known from Lào Cai Province, $\mathrm{Sa} \mathrm{Pa}$ environs, where the collecting was fulfilled this year [Ang \& Meier, 2010; Iwasa \& Thinh, 2008, 2012; Ozerov \& Krivosheina, $2011,2012]$. As a result, one more new to science species of the genus Dicranosepsis Duda, 1926 was discovered, the description of which is given below. Besides the genus Nemopoda Robineau-Desvoidy, 1830 with the species Nemopoda pectinulata Loew, 1873 is registered in Vietnam for the first time.

Terminology follows McAlpine [1981], Cumming et al. [2009], and Stuckenberg [1999]. The following abbreviation is used for depositories of the studied specimens: ZMUM - Zoological Museum, Moscow State University, Russia. Other abbreviations used in the text: $a$ - anterior; $d$ - dorsal; $p$ - posterior; $v$ ventral, and combinations of these latter four, all used for leg chaetotaxy; $b m$ - basal medial cell of wing; $b r$ - basal radial cell of wing.

\section{Taxonomic part \\ Dicranosepsis barbatula, sp.n.} Figs 1-2.

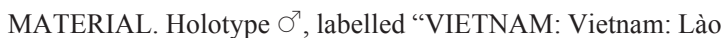
Cai Province, Sa Pa env (22.3303N, 103.8254E) (1284 m), 19.V.2014, coll. A.L.Ozerov" (in ZMUM). The holotype is pinned in exellent condition, right foreleg in tube with glycerol.

DESCRIPTION. Male. Head (Fig. 1) in lateral view slightly dorsoventrally flattened. Eye rounded. Frons black, shining. Face, gena and postcranium black, with whitish microtrichia. Antenna black. Postpedicel in profile oval, slightly longer than wide. 1 ocellar, 1 postocellar, 1 inner vertical, 1 outer vertical setae present; postgena with several setae (Fig. 1); 2-3 short vibrissae. Lateral occipital sclerite with several setulae.

Thorax black. Scutum microtrichose. Proepisternum microtrichose. Proepimeron shining in upper part and densely microtrichose in lower part. Anepisternum shining. Katepisternum shining, but along upper and posterior margins densely microtrichose. Anepimeron and pleural wing process microtrichose. Katepimeron, meron, metepisternum and metepimeron completely densely microtrichose. Katatergite and anatergite with dense grey microtrichia. Mediotergite shining under scutellum. Scutum with 1 postpronotal, 2 notopleural, 1 supra-alar, 1 postalar, and 2 postsutural dorsocentral setae; 1 long anepisternal (near posterior margin) seta 


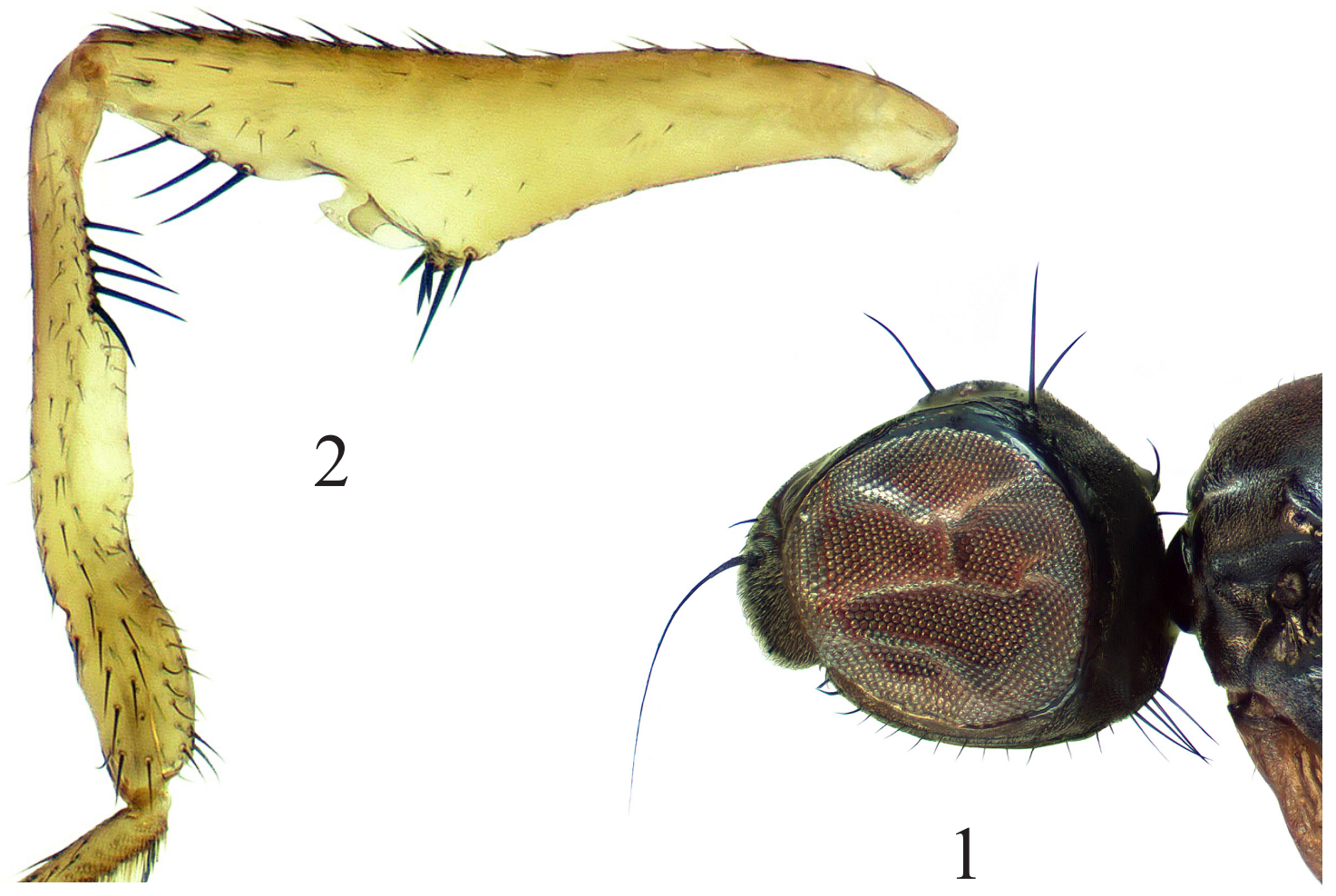

Figs 1-2. Dicranosepsis barbatula, sp.n., holotype $\sigma^{7}: 1$ - head, lateral view; 2 - fore right leg, anterior view.

Рис. 1-2. Dicranosepsis barbatula, sp.n., голотип ऽ : 1 - голова, сбоку; 2 - передняя правая нога, спереди.

present. Scutellum with pair of well-developed apical setae and pair of basal setulae. Postmetacoxal bridge present.

Legs yellow in ground colour, mid- and hind femora in apical part, mid tibia in basal half, hind tibia and tarsomeres of all legs darkened. Coxa of foreleg simple, without setae. Foreleg as in Fig. 2. Fore trochanter simple. Fore femur without $a v$ seta basally. Mid coxa bare. Mid femur with row of $a$ setae. Mid tibia with $3 a v$ in apical half. First tarsomere of midleg with row of moderate $a v$ setulae. Hind femur and hind tibia without striking setae. Hind tibia with hardly visible osmeterium-like area in apical half anterodorsally. First tarsomere of hindleg with row of long av setulae (which are as long as 3 width of first tarsomere), curved apically.

Wing normal, longer than abdomen, with moderately developed anal lobe; clear, without blackish spots or darkening; veins blackish. Cells $b m$ and $b r$ separate. Alula entirely covered with microtrichia, its width approximately 1.2 times as width of cell $\mathrm{bm}$. Upper calypter brownish, lower calypter black. Margin of upper calypter with hairs, margin of lower calypter without hairs. Halter yellowish.

Abdomen shining, strong constricted after syntergite $1+2$, without striking setae. Surstyli symmetrical, typical for species of genus Dicranosepsis.
Body length $2.6 \mathrm{~mm}$; wing length $2.2 \mathrm{~mm}$.

Female unknown.

COMPARISON. There is one more species with long genal setae - Dicranosepsis barbata Iwasa in Iwasa and Thinh, 2012. This species is described from Vietnam, Lào Cai and Lai Chau Provinces (Iwasa \& Thinh, 2012) also. The new species clearly differs in structure of male fore leg. Besides D. barbata has first tarsomere with rare short $a v$ setulae (which are as long as the width of first tarsomere), whereas first tarsomere of hindleg in D. barbatula with row of long av setulae, curved apically.

DISTRIBUTION. Vietnam.

Nemopoda pectinulata Loew, 1873

MATERIAL EXAMINED. VIETNAM: Lai Chau Province, 10 $\mathrm{km}$ WNW of Sa Pa $(22.3736 \mathrm{~N}, 103.7574 \mathrm{E}) 1810 \mathrm{~m}, 25$ and 26 . V.2014, A.L.Ozerov (2 $\sigma^{7} \sigma^{7}$, in ZMUM)

DISTRIBUTION. Widespread in Palaearctic; Oriental Region [Ozerov, 2005]: India (Jammu and Kashmir), Nepal, Taiwan, Vietnam (first rerord).

ACKNOWLEDGEMENTS. The authors would like to thank Dr. Nikita Vikhrev (ZMUM) for the organization of the collection trip to North Vietnam. 


\section{References}

Ang Y., Meier R. 2010. Five additions to the list of Sepsidae (Diptera) for Vietnam: Perochaeta cuirassa sp. n., Perochaeta lobo sp. n., Sepsis spura sp. n., Sepsis sepsi Ozerov, 2003 and Sepsis monostigma Thompson, 1869 // ZooKeys. Vol.70. P.41-56.

Cumming J.M., Wood D.M. 2009. Adult morphology and terminology // Brown B.V., Borkent A., Cumming J.M., Wood D.M., Woodley N.E., Zumbado M. (eds.). Manual of Central American Diptera. Vol. 1. National Research Council Press, Ottawa. P.9-50.

Iwasa M., Thinh T.H. 2008. Six new species of the genus Dicranosepsis Duda (Diptera, Sepsidae) from Vietnam, with a revised key to the species // Entomological Science. Vol.11. P.65-73.

Iwasa M., Thinh T.H. 2012. Taxonomic and faunistic studies of the Sepsidae (Diptera) from Vietnam, with descriptions of six new species // Entomological Science. Vol.15 P.99-114.
McAlpine J. F. 1981. Morphology and terminology-adults // McAlpine J.F., Peterson B.V., Shewell G.E, Teskey H.J., Vokeroth J.R., Wood D.M. (coordinators). Manual of Nearctic Diptera. Volume 2. Research Branch. Agriculture Canada. Monograph 27, Ottawa. P.9-63.

Ozerov A.L. 2005. World Catalogue of the family Sepsidae (Insecta: Diptera) // Zoologicheskie Issledovania. Moscow. No.8. 74 p.

Ozerov A.L. 2012. A new genus and three new species of the family Sepsidae (Diptera) from China and Vietnam // Russian Entomological Journal. Vol.21. No.1. P.113-116.

Ozerov A.L., Krivosheina M.G. 2011. Two new species of Sepsidae (Diptera) from Vietnam // Russian Entomological Journal. Vol.20. No.2. P.211-214.

Ozerov A.L., Krivosheina M.G. 2012. New species of Sepsidae and Scathophagidae (Diptera) from Vietnam //Russian Entomological Journal. Vol.21. No.3. P.331-335.

Stuckenberg B.R. 1999. Antennal evolution in the Brachycera (Diptera), with a reassessment of terminology relating to the flagellum // Studia Dipterologica. Vol.6. S.33-48. 